\title{
EFEKTIVITAS PENGINTEGRASIAN PENDIDIKAN KARAKTER DI PERGURUAN TINGGI MELALUI TEKNIK KLARIFIKASI NILAI PADA MATA KULIAH PENDIDIKAN KEWARGANEGARAAN
}

\author{
Maryatun Kabatiah \\ 1) Universitas negeri Medan, Sumatera Utara, Indonesia \\ maryatunkabatiah@unimed.ac.id
}

\begin{abstract}
Civic Education is a very important subject in efforts to build the nation's character. Character building through Civics includes integrating character values in lectures. Value clarification techniques are considered superior for affective learning (learning to form attitudes/values). Through value clarification, learning activities no longer require students to memorize and understand the values that have been chosen by others, but are assisted in finding, analyzing, taking responsibility, developing, choosing, taking attitudes, and practicing the values in their own lives. This research is a pre-experimental research design. The method used in this research is the Intact Group Comparison design method. The research subjects were students of the Department of Early Childhood Education (PAUD) UNJA who took the general course of civic education. Subjects were divided into 2 groups, namely the control group using the conventional approach, and the experimental group using the Value clarification techniques. The instrument used in this study is a test instrument. The collected data were analyzed using the t-test. Based on the results of the study, it can be concluded that the integration of character education in civic education courses through Value clarification techniques is more effective than conventional ones
\end{abstract}

Keywords: character education, civic education, VCT

\begin{abstract}
Abstrak
Pendidikan Kewarganegaraan merupakan mata kuliah yang sangat penting dalam upaya pembangunan karakter bangsa. Pembangunan karakter melalui PKn di antaranya pengintegrasian nilai-nilai karakter dalam perkuliahan. Teknik klarifikasi nilai dianggap lebih unggul untuk pembelajaran afektif (pembelajaran pembentukan sikap/nilai). Melalui pengklarifikasian nilai, kegiatan pembelajaran tidak lagi sekedar menuntut peserta didik agar hafal dan paham akan nilai-nilai yang sudah dipilihkan pihak lain, melainkan dibantu untuk mencari, menganalisa, mempertanggung jawabkan, mengembangkan, memilih, mengambil sikap, dan mengamalkan nilai-nilai dalam kehidupannya sendiri. Penelitian ini adalah penelitian Pre-Eksperimental Design. Metode yang digunakan dalam penelitian ini adalah metode rancangan Intact Group Comparison. Subjek penelitian adalah mahasiswa Jurusan Pendidikan Anak Usia Dini (PAUD) UNJA yang mengikuti mata kuliah umum PKn. Subjek dibagi menjadi 2 kelompok yakni kelompok
\end{abstract}


kontrol dengan menggunakan pendekatan konvensional, dan eksperimen menggunakan Teknik klarifikasi nilai. Instrumen yang digunakan dalam penelitian ini adalah instrumen tes. Data yang terkumpul dianalisis dengan menggunakan uji t. Berdasarkan hasil penelitian dapat disimpulkan pengintegrasian pendidikan karakter dalam mata kuliah PKn melalui Teknik klarifikasi nilai lebih efektif dibandingkan dengan konvensional.

Kata kunci: pendidikan karakter, pendidikan kewarganegaraan, VCT

\section{PENDAHULUAN}

Pendidikan karakter senantiasa menjadi topik yang marak dibicarakan pada level pendidikan dalam dua dekade terakhir. Komitmen secara nasional untuk menanamkan karakter melalui dunia pendidikan tertuang dalam Pasal 3 UU No. 20 Tahun 2003 tentang Sistem Pendidikan Nasional yang menyatakan bahwa "pendidikan nasional berfungsi mengembangkan kemampuan dan membentuk watak serta peradaban bangsa yang bermartabat dalam rangka mencerdaskan kehidupan bangsa, bertujuan untuk berkembangnya potensi peserta didik agar menjadi manusia yang beriman dan bertakwa kepada Tuhan Yang Maha Esa, berakhlak mulia, sehat, berilmu, cakap, kreatif, mandiri, dan menjadi warga negara yang demokratis serta bertanggung jawab." Selanjutnya pendidikan karakter juga menjadi sasaran dari pembangunan nasional sebagaimana yang termaktub dalam Undang-Undang No. 17 Tahun 2007 tentang Rencana Pembangunan Jangka Panjang Nasional Tahun 2005-2025, antara lain adalah dalam "mewujudkan masyarakat yang berakhlak mulia, bermoral, beretika, berbudaya, dan beradab berdasarkan falsafah Pancasila". Dalam hal ini berarti karakter merupakan suatu proses penanaman nilai termasuk di dalamnya budi pekerti, perilaku, moral yang berujung kepada hal positif dalam bentuk sikap yang baik dalam kehidupan sehari-hari.

Lickona (2012) mengatakan bahwa karakter merupakan kepemilikan terhadap halhal yang baik, untuk menggambarkan bagaimana karakter melibatkan pengetahuan moral (knowing of good), perasaan moral (feeling the good), dan tindakan moral (acting the good). Kehidupan yang penuh kebajikan (the virtuouslife) sendiri oleh Lickona dibagi dalam dua kategori, yakni kebajikan terhadap diri sendiri (self-oriented virtuous) seperti pengendalian diri (selfcontrol) dan kesabaran (moderation); dan kebajikan terhadap orang lain (other-oriented virtuous), seperti kesediaan berbagi (generousity) dan merasakan kebaikan (compassion).

Nilai-nilai karakter diyakini sebagai dasar dalam mendukung keberlangsungan bangsa dan negara. Sebagaimana yang dikemukakan oleh Raths, Harmin \& Simon (dalam Adisusilo, 2012) "values are general guides to behavior which tend to give direction to life", nilai merupakan panduan umum untuk membimbing tingkah laku dalam rangka mencapai tujuan hidup seseorang. Salah satu upaya untuk untuk memperkuat jati diri dan karakter bangsa adalah melalui pendidikan. Pendidikan karakter merupakan wadah pendidikan nilai, budi pekerti, moral dan pendidikan watak yang bertujuan mengembangkan sikap dan kemampuan seluruh masyarakat agar dapat mempertimbangkan perbuatan baik-buruk, menanam kedisiplinan, menjadi contoh teladan, serta mempertahankan dan mewujudkan nilai-nilai kebaikan itu dalam kehidupannya secara mandiri tanpa ada paksaaan dari pihak manapun.

\section{JURNAL KEWARGANEGARAAN}


Pendidikan karakter di perguruan tinggi merupakan tahapan pembentukan karakter yang tidak kalah penting dari pembentukan karakter di tingkat sekolah, hal ini karenakan pendidikan karakter di perguruan tinggi merupakan kelanjutan dari pendidikan karakter di persekolahan. Salah satu mata kuliah yang mengemban misi pendidikan karakter di Perguruan Tinggi adalah mata kuliah Pendidikan Kewarganegaraan (Selanjutnya disebut PKn). Melalui koridor "value-based education", PKn menjadi salah satu bidang kajian yang mengemban misi nasional untuk mencerdaskan kehidupan bangsa Indonesia (Budimansyah, Ruyadi, \& Rusmana, 2010). PKn baik dalam pendidikan formal (di sekolah dan perguruan tinggi), non formal (pendidikan di luar sekolah), maupun informal (pergaulan di rumah dan masyarakat), mempunyai visi sebagai wahana substantif, pedagogis, dan sosial-kultural untuk membangun cita-cita, nilai, konsep, prinsip, sikap, dan keterampilan kewarganegaraan dalam diri warga negara dalam berbagai konteks (Winataputra, 2015). Pembangunan karakter melalui mata kuliah PKn di antaranya adalah dengan pengintegrasian nilai-nilai karakter dalam perkuliahan. Karakter tersebut antara lain memiliki nilai kekuatan spiritual keagamaan, moral, pengendalian diri, kepribadian serta akhlak mulia.

Pengintegrasian pendidikan karakter dalam perkuliahan PKn membutuhkan suatu strategi atau rencana yang disusun sesuai dengan kebutuhan peserta didik, monitoring dan evaluasinya pun harus sudah disusun dengan baik. Hal ini dilakukan agar indoktrinasi dalam pengintegrasian nilai-nilai karakter dapat dihindari, indoktrinasi dalam pengintegrasian nilai harus dihindari karena dikhawatirkan nilai-nilai karakter yang hendak ditanamkan menjadi tidak terinternalisasi apalagi diamalkan, karena kegiatan pembelajaran hanya sebatas pengenalan dan penghafalan nilai-nilai yang sudah ada atau ditetapkan oleh orang lain. Oleh karena itu mengingat mahasiswa sebagai kelompok idealis dengan segala kelebihan dan potensinya, pemberian pendidikan karakter bangsa kepada mereka memerlukan pendekatan pembelajaran yang khusus.

Menurut Simon (dalam Adisusilo, 2012) Pendekatan pendidikan nilai dapat digolongkan menjadi empat, yaitu: (1) Memoralisasi (Moralizing), (2) Bersikap Membiarkan (Laissez-faire Attitude), (3) Menjadi Model (Modelling), (4) Teknik klarifikasi nilai/Value clarification technique (selanjutnya disebut VCT), bentuk dari pengembangan model ini dapat berupa pemecahan masalah, dialog, diskusi kelompok, dan presentasi. Di antara keempat pendekatan diatas, pendekatan VCT dianggap lebih efektif untuk pembelajaran pembentukan sikap dan pengintrasian nilai. Karena dengan klarifikasi nilai, peserta didik tidak disuruh menghafal nilai-nilai yang sudah dipilihkan pihak lain, melainkan dibantu untuk mencari, menganalisa, mempertanggung jawabkan, mengembangkan, memilih, mengambil sikap, dan mengamalkan nilai-nilai dalam kehidupannya sendiri (Simon dalam Adisusilo, 2012). Strategi instruksional yang digunakan dalam Pendekatan ini, pada dasarnya bertolak dari strategi "inquiry learning, discovery learning, problem solving learning, research-oriented learning (belajar melalui penelitian, penyingkapan, pemecahan masalah)". Dalam penelitian ini strategi yang digunakan adalah problem solving learning.

\section{METODE PENELITIAN}

Penelitian ini merupakan pre-eksperimental design dengan metode rancangan intact group comparison yaitu penelitian variabel dengan membagi dua kelompok, yaitu kelompok eksperimen dan kelompok kontrol (Sugiyono, 2010). Adapun subjek penelitian 
adalah mahasiswa Jurusan Pendidikan Anak Usia Dini (PAUD) UNJA yang mengikuti mata kuliah umum PKn. Subjek dibagi menjadi 2 kelompok yakni kelompok kontrol dengan menggunakan pendekatan konvensional, dan kelompok eksperimen menggunakan teknik klarifikasi nilai. Pengambilan subjek berdasarkan teknik purposive sampling yakni berdasarkan pada pertimbangan dan atau tujuan tertentu, serta berdasarkan karakteristik tertentu yang sebelumnya sudah diketahui (Arifin, 2012). Alasannya adalah karena diperlukan dua kelas yang homogen kemampuannya serta dapat mewakili karakteristik populasi. Selain itu kedua kelas memiliki ciri-ciri yang sama yakni merupakan kelas reguler sehingga kemampuan mahasiswa dianggap setara.

Teknik pengumpulan data yang digunakan adalah tes yakni hasil belajar kedua kelompok (eksperimen dan kontrol) guna mengetahui perbedaan tingkat efektivitas pengintegrasian pendidikan karakter melalui pendekatan VCT dan pendekatan konvensional. Teknik analisis data yang digunakan meliputi uji instrumen (uji validitas dan reliabilitas), uji normalitas, uji homogenitas dan uji hipotesis menggunakan uji t.

\section{HASIL DAN PEMBAHASAN}

PKn memiliki tiga domain, yakni domain akademik; domain kurikuler; domain sosial-kultural (Winataputra, 2001). Berbagai pemikiran tentang Pendidikan Kewarganegaraan yang berkembang di lingkungan komunitas keilmuan berada pada domain akademik adalah. Sementara konsep dan praksis pendidikan kewarganegaraan dalam lingkup pendidikan formal dan nonformal berada pada domain kurikuler. Sedangkan konsep dan praksis Pendidikan Kewarganegaraan di lingkungan masyarakat berada pada domain sosial kultural (Wahab \& Sapriya, 2011). Dengan demikian PKn domain kurikuler merupakan penempatan PKn dalam pendidikan formal (jenjang SD sampai perguruan tinggi) dan juga dalam pendidikan nonformal. Dalam domain ini PKn selain sebagai mata pelajaran yang diterapkan di persekolahan, PKn juga berfungsi sebagai mata kuliah di perguruan tinggi. Sebagaimana yang terdapat dalam Surat Keputusan Dirjen Dikti Nomor 43 Tahun 2006 tentang Rambu-rambu Pelaksanaan Mata Kuliah pengembangan Kepribadian di Perguruan Tinggi bahwa PKn merupakan bagian dari kelompok mata kuliah pengembangan kepribadian yang wajib diberikan pada semua jurusan di seluruh perguruan tinggi.

Sebagai mata kuliah pengembangan kepribadian PKn sangat erat kaitannya dengan pengintegrasian nilai-nilai atau pendidikan nilai yakni bagaimana menginternalisasikan nilai-nilai yang harus dimiliki, dihayati dan diamalkan oleh seluruh masyarakat kepada peserta didik. Namun sebagai pusat pendidikan nilai, PKn bukanlah sekedar mentransmisikan nilai tertentu kepada peserta didik, tetapi dimaknai sebagai upaya mengembangkan proses penilaian dalam diri seseorang, semacam suatu keyakinan untuk memperkaya peserta didik dengan sesuatu yang lebih krusial dan fungsional (Aryani \& Susatim, 2010). PKn dirumuskan secara luas yaitu mencakup proses penyiapan generasi muda atau warga negara menjadi lebih baik, demokratis, jujur, bertanggung jawab, mempunyai wawasan dan jiwa patriotisme, nasionalisme pada negara. Sedangkan secara khusus, peran pendidikan termasuk di dalamnya persekolahan, pengajaran dan belajar, dalam proses penyiapan warga negara tersebut menjadi warga negara yang ideal baik untuk dirinya, lingkungan dan juga masa depan bangsa (Hendri, 2020).

\section{JURNAL KEWARGANEGARAAN}


Tujuan utama dari pembelajaran PKn adalah untuk membentuk pribadi yang cerdas, terampil, demokratis, sesuai dengan nilai-nilai Pancasila untuk mewujudkan Indonesia yang demokratis, mempunyai warga negara yang bermoral dan mempunyai nilai-nilai kebangsaan yang tinggi. PKn harus mampu mempersiapkan peserta didik agar dapat menjadi generasi penerus bangsa melalui pengetahuan dan keterampilan intelektual yang memadai serta pengalaman praktis agar memiliki kompetensi dan efektivitas dalam berpartisipasi. Materi PKn memprioritaskan pada pembentukan diri yang beragam, baik dari segi agama, sosio-kultural, bahasa, usia, dan suku bangsa, untuk menjadi warga negara Indonesia yang cerdas, terampil, dan berkarakter. PKn sebagai mata kuliah yang mengemban misi pendidikan karakter, perlu mengukuhkan posisinya menjadi subjek pembelajaran nilai yang kuat. Pembangunan karakter melalui mata kuliah PKn di antaranya adalah dengan mengintegrasikan nilai-nilai karakter dalam perkuliahan.

Sebagai langkah awal dalam pengintegrasian nilai-nilai karakter perlu dilakukan sebuah inovasi pembelajaran dengan penggunaan pendekatan dan metode pembelajaran yang tepat, penanaman nilai tidak cukup hanya menggunakan metode ceramah murni, tetapi perlu divariasikan dengan metode pembimbingan yang dapat mengungkapkan nilai, seperti analisis nilai dan VCT. Sebagaimana yang dikemukakan oleh Hall (dalam Adisusilo, 2012), bahwa melalui VCT peserta didik tidak lagi menghafal nilai-nilai yang dipilih oleh orang lain melainkan dibantu untuk mencari, menganalisis, mengembangkan, memilih, mengambil sikap dan mengamalkan nilai-nilai ia pilih sendiri. Peserta didik tidak dipilihkan nilai yang baik dan benar untuk dirinya, melainkan diberi kesempatan untuk menentukan pilihan sendiri terhadap nilai-nilai mana yang mau dikejar, diperjuangkan dan diamalkan dalam hidupnya.

VCT merupakan salah satu pendekatan yang dapat memenuhi tujuan pencapaian pendidikan nilai, karena pada prosesnya VCT berfungsi untuk: a) mengukur atau mengetahui tingkat kesadaran mahasiswa tentang suatu nilai; b) membina kesadaran mahasiswa tentang nilai-nilai yang dimilikinya baik yang positif maupun yang negatif untuk kemudian dibina ke arah peningkatan atau pembetulannya; c) menanamkan suatu nilai kepada mahasiswa melalui cara yang rasional dan diterima mahasiswa sebagai milik pribadinya. Dengan kata lain, VCT dimaksudkan untuk membiasakan dan membimbing mahasiswa tentang bagaimana cara menilai, mengambil keputusan terhadap suatu nilai umum untuk kemudian dilaksanakannya sebagai warga masyarakat. Langkah-langkah VCT yang digunakan dalam pembelajaran di kelas eksperimen antara lain: Pertama, penentuan stimulus yang bersifat dilematik melalui peragaan, membacakan, atau meminta bantuan mahasiswa untuk memeragakan, yang melahirkan kegiatan yang meliputi: pengungkapan masalah, identifikasi fakta yang dimuat stimulus, menentukan kesamaan pengertian yang perlu, menentukan masalah utama yang akan dipecahkan VCT; kedua, penentuan pendapat berupa penentuan pilihan individual, penentuan pilihan kelompok dan kelas, klasifikasi atas pilihan tersebut); ketiga, menguji alasan, yakni mencakup kegiatan: meminta argumentasi mahasiswa/ kelompok /kelas, pemantapan argumentasi melalui: mempertentangkan argumen demi argumen, penerapan kejadian secara analogis, mengkaji akibat-akibat penerapan tersebut, mengkaji kemungkinan dari kenyataan; keempat, pada tahapan penyimpulan dan pengarahan dilakukan penarikan kesimpulan melalui: para mahasiswa/kelompok/kelas, dan penyimpulan dan pengarahan oleh dosen, dan yang kelima adalah tindak lanjut (follow up), tindakan lanjutan berupa kegiatan perbaikan atau pengayaan, kegiatan ekstra/ latihan /uji coba penerapan. Hasil 
dari seluruh kegiatan akan dikumpulkan dalam satu portofolio, untuk kemudian dievaluasi.

Berdasarkan analisis deskriptif data penelitian terhadap hasil belajar mahasiswa di kelas kontrol dan eksperimen, diperoleh hasil bahwa nilai rerata (mean) kelas eksperimen lebih tinggi dibandingkan dengan kelas kontrol, yakni kelas eksperimen dengan nilai mean 78,81, sedangkan untuk kelas kontrol adalah 70,24. Selanjutnya dilakukan uji prasyarat meliputi dua uji yaitu uji normalitas dan homogenitas. Dari hasil uji normalitas yang dilakukan didapatkan hasil sig. kelas eksperimen dan kelas kontrol adalah 0,173. Dengan demikian dapat disimpulkan bahwa kelas kontrol mempunyai probabilitas lebih besar dari 0,05 atau dengan kata lain bahwa data berdistribusi normal. Sedangkan untuk kelas eksperimen mempunyai nilai probabilitas yang lebih besar dari 0,05 atau dengan kata lain data kemampuan berpikir kritis kelas eksperimen berdistribusi normal. Sementara uji homogenitas adalah suatu uji prasyarat yang berfungsi untuk mengetahui kehomogenitasan data penelitian. Hasil uji homogenitas yang dilakukan mendapatkan hasil adalah 0.835. Berdasarkan hasil tersebut disimpulkan bahwa kelas kontrol dan eksperimen mempunyai probabilitas lebih besar dari 0,05 atau dengan kata lain bahwa data kelas kontrol dan eksperimen mempunyai varian yang sama atau homogen.

Analisis data terakhir sebagai dasar pengambilan keputusan dan pengujian hipotesis adalah uji-t yang menggunakan independent sample t-test sebagaimana yang terlihat pada tabel berikut:

Tabel 1. Hasil Uji t Skor Hasil Belajar PKn Kelompok Eksperimen dan Kelompok Kontrol

\begin{tabular}{|c|c|c|c|c|c|c|c|c|c|c|}
\hline \multirow[b]{4}{*}{$\begin{array}{l}\text { Hasil } \\
\text { Belajar }\end{array}$} & \multirow[b]{4}{*}{$\begin{array}{l}\text { Equal } \\
\text { variance } \\
\text { assumed }\end{array}$} & \multicolumn{9}{|c|}{ Levene's Test For Equality of Variance } \\
\hline & & \multirow[t]{2}{*}{$\mathrm{f}$} & \multirow[t]{2}{*}{ sig } & \multirow[t]{2}{*}{$\mathrm{t}$} & \multirow[t]{2}{*}{ Df } & \multirow[t]{2}{*}{$\begin{array}{c}\text { Sig. } \\
(2-\text { talled) }\end{array}$} & \multirow[t]{2}{*}{$\begin{array}{c}\text { Mean } \\
\text { Difference }\end{array}$} & \multirow[t]{2}{*}{$\begin{array}{l}\text { Std.error } \\
\text { Difference }\end{array}$} & \multicolumn{2}{|c|}{$\begin{array}{l}95 \% \text { Confidence } \\
\text { Interval of the } \\
\text { Difference }\end{array}$} \\
\hline & & & & & & & & & Lower & Upper \\
\hline & & .144 & .042 & 2.085 & 28 & .019 & -8557 & 3.6864 & -18.0410 & -6.1539 \\
\hline & $\begin{array}{l}\text { Equal } \\
\text { variance not } \\
\text { assumed }\end{array}$ & & & 2.077 & 23.653 & .019 & -8557 & 3.5233 & -17.4823 & -8.8236 \\
\hline
\end{tabular}

Berdasarkan hasil uji independent sample t-test menunjukkan bahwa hasil $\mathrm{t}$ hitung lebih besar dari tabel dan signifikansi yang lebih kecil dari 0,05. Sebagaimana diketahui

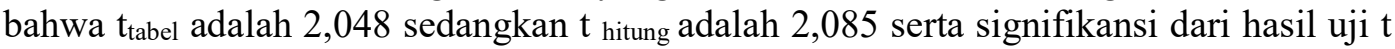
independent sample t test adalah 0,002 $<0,05$ maka dapat disimpulkan bawa $t_{\text {hitung }}>$ dari $t_{\text {tabel }}$ atau 2,085>2,048 dan signifikansi lebih kecil dari 0,05 atau 0,042<0,05. Dari kesimpulan tersebut, dapat diputuskan bahwa Ho ditolak sehingga Ha diterima. Hal ini berarti terdapat perbedaan tingkat efektivitas pengintegrasian pendidikan karakter melalui pendekatan VCT dengan pendekatan konvensional dalam mata kuliah PKn. Dengan demikian dapat disimpulkan bahwa pengintegrasian pendidikan karakter dalam mata kuliah PKn melalui pendekatan VCT lebih efektif dibandingkan dengan pendekatan konvensional. Sebagaimana yang dikemukakan Cheppy (dalam Adisusilo, 2012) kekuatan pendekatan ini adalah memberikan penghargaan yang tinggi kepada peserta didik sebagai individu yang mempunyai hak dan kebebasan untuk memilih dan menentukan sikap dan bertindak berdasarkan kepada nilainya sendiri.

\section{JURNAL KEWARGANEGARAAN}


Pendekatan VCT terbukti lebih efektif dalam pengintegrasian pendidikan karakter pada mata kuliah PKn karena pendekatan VCT lebih menekankan bagaimana sebenarnya seseorang membangun nilai yang menurut anggapannya baik, yang nantinya nilai-nilai tersebut tercermin dalam perilaku dalam kehidupan di masyarakat. Dengan klarifikasi nilai, seseorang tidak disuruh menghafal nilai-nilai yang sudah dipilihkan pihak lain, melainkan dibantu untuk menemukan, menganalisa, mempertanggung jawabkan, mengembangkan, memilih, mengambil sikap, dan mengamalkan nilai-nilai dalam kehidupannya sendiri. VCT lebih efektif karena mempunyai tahapan-tahapan dimana peserta didik diberi keleluasaan dalam menentukan dan memilih nilai-nilai yang akan diinternalisasikan dalam kehidupannya, dalam hal ini peserta didik menempuh tahapan klarifikasi nilai diantaranya: Pertama, kebebasan memilih, terdiri tiga tahap yaitu: (a) memilih secara bebas, artinya kesempatan untuk menentukan pilihan yang menurutnya baik; (b) memilih dari berbagai alternatif, artinya menentukan pilihan dari beberapa alternatif pilihan secara bebas; dan (c) Memilih setelah dilakukan analisis pertimbangan konsekuensi yang akan timbul sebagai akibat pilihannya. Kedua, tahap menghargai, terdiri dari dua tahap yaitu: (a) adanya perasaan senang dan bangga dengan nilai yang; menjadi pilihannya; (b) menegaskan nilai yang sudah menjadi bagian integral dalam dirinya di depan umum. Ketiga, tahap berbuat, terdiri dari dua tahap yaitu: (a) kemauan dan kemampuan untuk mencoba melaksanakannya; (b) mengulangi perilaku sesuai dengan nilai pilihannya, artinya nilai yang menjadi pilihannya harus tercermin dalam kehidupan sehari-hari (Jerolemik dalam Sanjaya, 2008).

Dengan demikian pendekatan VCT dapat melatih mahasiswa untuk berproses melakukan penilaian terhadap nilai-nilai kehidupan yang ada dalam masyarakat dan dapat menetapkan nilai-nilai yang menjadi acuan hidupnya untuk perilaku dalam kehidupan di masyarakat. Pada saat para mahasiswa diperkenalkan pada sejumlah persoalan yang terkait dengan bahan pelajaran akan menyadarkan mereka bahwa belajar sesungguhnya harus sampai pada adanya upaya untuk menyelesaikan persoalan kehidupan berdasarkan nilai-nilai yang kita yakini, bukan menghafalkan seonggok fakta dan data.

Pendekatan VCT tentunya juga mengandung kelemahan sebab kriteria benar-salah dapat bersifat relatif, dan sangat mementingkan nilai perseorangan. VCT memang dikembangkan dalam budaya barat yang cenderung amat individualistis dan liberal. Oleh sebab itu, seorang pendidik harus bijak dalam memberi pendampingan agar dalam pemilihan, penentuan nilai, peserta didik tidak tercabut dari akar budayanya. Dalam tatanan bangsa Indonesia tentunya batasan nilai-nilainya adalah nilai-nilai pancasila itu sendiri.

\section{KESIMPULAN}

Berdasarkan analisis deskriptif data penelitian diperoleh hasil bahwa nilai rerata (mean) kelas eksperimen lebih tinggi dibandingkan dengan kelas kontrol, yakni kelas eksperimen dengan nilai mean 78,81, sedangkan untuk kelas kontrol adalah 70,24. Selanjutnya dari hasil uji hipotesis didapat bahwa $t_{\text {hitung }}>t_{\text {tabel }}$ atau 2,085 $>2,048$ dan signifikansi lebih kecil dari 0,05 atau 0,042<0,05. Dari hasil tersebut, dapat diputuskan bahwa Ho ditolak sehingga Ha diterima, sehingga dapat disimpulkan bahwa terdapat perbedaan tingkat efektivitas pengintegrasian pendidikan karakter melalui pendekatan VCT dengan pendekatan konvensional dalam mata kuliah PKn. 


\section{UCAPAN TERIMA KASIH}

Ucapan terimakasih yang sedalam-dalamnya penulis haturkan seluruh pimpinan Universitas Jambi dan LPPM Universitas Jambi yang telah memberikan dukungan secara penuh terhadap keterlaksanaan penelitian ini. Selanjutnya penulis juga mengucapkan terimakasih kepada keluarga, kolega dan semua pihak yang telah membantu dan memberikan dukungan baik secara langsung maupun tidak langsung sehingga karya ilmiah ini dapat diselesaikan.

\section{DAFTAR PUSTAKA}

Adisusilo, S. (2012). Pembelajaran Nilai-Karakter: Konstruktivisme dan VCT sebagai Inovasi Pendekatan Pembelajaran Afektif. Jakarta: PT Raja Grafindo Persada.

Arifin, Z. (2012). Penelitian Pendidikan: Metode dan Paradigma Baru. Bandung: PT Remaja Rosdakarya.

Aryani, I. K., \& Susatim, M. (2010). Pendidikan Kewarganegaraan Berbasis Nilai. Bogor: Ghalia Indonesia.

Budimansyah, D., Ruyadi, Y., \& Rusmana, N. (2010). Model Pendidikan Karakter di Perguruan Tinggi. Bandung: Universitas Pendidikan Indonesia.

Hendri. (2020). Penguatan Pendidikan Kewarganegaraan Melalui Pendidikan Pesantren dalam Membentuk Keadaban Moral Santri. Jurnal Kewarganegaraan, 17(1), 35. https://doi.org/10.24114/jk.v17i1.18702

Lickona, T. (2012). Mendidik Untuk Membentuk Karakter: Bagaimana Sekolah Dapat Memberikan Pendidikan tentang Sikap Hormat dan Tanggung Jawab (J. A. Wamaungo, Penerj.). Jakarta: Bumi Aksara.

Sanjaya, W. (2008). Strategi Pembelajaran Berorientasi Standar Proses Pendidikan. Jakarta: Kencana.

Sugiyono. (2010). Metode Penelitian Kuantitatif, Kualitatif dan R\&D. Bandung: Alfabeta.

Surat Keputusan Direktur Jenral Pendidikan Tinggi Nomor 43 Tahun 2006 tentang Rambu-rambu Pelaksanaan Mata Kuliah pengembangan Kepribadian di Perguruan Tinggi.

Undang-Undang Republik Indonesia Nomor 17 Tahun 2007 tentang Rencana Pembangunan Jangka Panjang Nasional Tahun 2005-2025.

Undang-Undang Republik Indonesia Nomor 20 Tahun 2003 tentang Sistem Pendidikan Nasional.

Wahab, A. A., \& Sapriya. (2011). Teori dan Landasan Pendidikan Kewarganeraan. Bandung: Alfabeta.

Winataputra, U. S. (2001). Apa dan Bagaimana Pendidikan Kewarganegaraan. Makalah Lokakarya Civic Education Dosen IAIN/STAIN Se-Indonesia, Sawangan Depok.

\section{JURNAL KEWARGANEGARAAN}


Winataputra, U. S. (2015). Pendidikan Kewarganegaraan: Refleksi Historisepistemologis dan Rekonstruksi untuk Masa Depan. Tangerang Selatan: Universitas Terbuka. 